\title{
A Impact Study on Sericulture Production Technologies by the Farmers of Bidar District in Karnataka, India
}

\author{
D.K. Hadimani ${ }^{1}$, Moulasab ${ }^{2 *}$, J. Ashoka ${ }^{1}$ and Manjunath ${ }^{2}$ \\ ${ }^{1}$ Department of Sericulture, University of Agricultural Sciences, Raichur, Karnataka, India \\ ${ }^{2}$ Department of Agricultural Extension, University of Agricultural Sciences, \\ Raichur, Karnataka, India \\ *Corresponding author
}

\section{A B S T R A C T}

\section{Keywords}

Knowledge level, Improved sericulture production technologies, Profile analysis, Socioeconomic characters.

Article Info

Accepted:

17 September 2017 Available Online: 10 November 2017
The study was conducted to know the knowledge level of improved sericulture production technologies of farmers in Bidar district of north Karnataka during the year 2016-2017. Major findings revealed that more than half $(54.00 \%)$ of the respondents belonged to medium knowledge level category. While 26 per cent of the respondents possessed low knowledge and high knowledge level was noticed among only 20 per cent of respondents about improved sericulture production technologies. The variables namely education, faming experience in sericulture, extension participation, extension contact, scientific orientation and risk orientation were found important in influencing the knowledge level of the sericulture farmers about improved sericulture production technologies.

\section{Introduction}

Sericulture is a cottage industry par excellence with its agriculture base, industrial super structure and labour intensive nature. Of late sericulture has become one of the most important rural industries due to certain inherent advantages like minimum gestation period and expenditure, maximum employment potentiality and quick turnover of investment

India is the largest consumer of natural silk in the world and the demand for silk is consistently increasing in the country. As a result, the demand- supply gap is widening in mulberry raw silk. Hence, there is an urgent need to improve the production, productivity and quality of Indian silk for meeting the import substitute for domestic market and compete in the international market especially in the changing scenario of global trade. Among the Sericultural countries India stands second in the production of silk. Sericulture plays a key role in the up-liftment of rural population both socially and economically. In the past two decades various technologies have been developed both in the improvement of mulberry yield and silkworm rearing technology by the concerted efforts of scientists in order to overcome the constraints and boost the silk production of the country 
(Meenal, 2008). In Karnataka, the premier silk producing state in the country, the average productivity level of the cocoon was 789 kg/ha during 2013-14 (Department of Sericulture, Government of Karnataka) as against the potential yield of $1,500 \mathrm{~kg} / \mathrm{ha}$.

Sericulture has been practiced since several decades, the dynamic changes in the field of sericulture research and development have been brought during the last three decades, mainly due to introduction of better mulberry varieties and silkworm races and improved cultural and rearing practices. Though extension network has been established at national and state level to educate sericulturists, a wide gap exists between the recommended technology and actual adoption by sericulturists. To plans a suitable intervention strategy, to bridge this gap, it is necessary to understand present knowledge level for improved production technologies and socio-economic profile of the farmers. It is, therefore, present study was conducted to know the extent of knowledge of improved sericulture production technologies and profile analysis of farmers of Bidar district of Karnataka state

\section{Materials and Methods}

The study was conducted in Bidar districts of north Karnataka state during the year 201617. The two tehsils i.e. Humnabad and Balki from Bidar district were selected for the study. Thereafter, 5 villages having the highest area under mulberry cultivation were selected from each tehsil. 10 respondents were selected randomly from each village. 100 respondents were selected from the selected 10 villages by adopting simple random sampling. Ex-post facto design was employed for conducting the study. Data was collected by using a detailed interview schedule employing personal interview method. Statistical tools like percentage, mean, standard deviation and correlation coefficient were used to analyse the data.

\section{Results and Discussion}

\section{Personal and socio-economic profile of the respondents}

It is clear from the Table 1 that majority $(56.00 \%)$ of the respondents were under middle age category. Whereas, 22 per cent were belonged to young age group and 21.00 per cent of them belonged to old age category. These middle age farmers were highly enthusiastic, had more working efficiency and high risk bearing capacity than older and younger farmers. With respect to education, 27.00 per cent of the respondents had high school education followed by 25 per cent of the respondents had middle school and 20 per cent of them were illiterate. Very less $(12.00 \%)$ per cent of the respondent's educated up to primary school and graduation and above $(7.00 \%)$. The probable reason may be better awareness about the importance of education and proper facilities of schooling available in vicinity of villages. Majority $(60.00 \%)$ of the respondents had agriculture as main occupation and 20 per cent of them engaged in agriculture with subsidiary enterprises. The majority of farmers practicing agriculture alone might be due to the continuation of ancestral traditional occupation of agriculture. With respect to annual income half $(50.00 \%)$ of the respondents were in medium income group (1.37-3.50 lakh) followed by 34.17 per cent were in low income group (less than 1.37 lakh) and 15.83 per cent were in high income group (more than 3.50 lakh). Regarding farming experience in sericulture, 54 per cent of the respondents had medium farming experience (4-8 year). Whereas, 26 per cent of respondents had low faming experience (less than 4) and 20 per cent of the them had high farming experience (above 8 years). The 
reason for medium farming experience due to the majority of the respondents was in middle and old age group. Majority $(47.00 \%)$ of the respondents belonged to medium mass media participation. Whereas, 27.00 per cent and 16 per cent of the respondents belonged to low and high mass media participation. This was due to the fact that majority of the respondents were educated and they tend to expose themselves to print and electronic media.

With regard to extension participation, more than half $(55.00 \%)$ of the respondents had medium extension participation followed by 27 per cent of the respondents had low extension participation and 18.00 per cent of them had high extension participation. The probable reason for majority of farmers in medium category might be because of their interest in extension activities to gather recent information and their education level. With respect to extension contact, more than half $(62.00 \%)$ of the respondents belonged to medium extension contact.

With regard to scientific orientation, 54.00 per cent of the respondents had medium scientific knowledge about sericulture production technologies followed by 30 per cent had low scientific knowledge.

Only 16 per cent had high scientific knowledge. Majority of the respondents belonged medium $(44.00 \%)$ and high $(32.00 \%)$ risk orientation. The above results are in line with the findings of Mech et al., (2004), Borah et al., (2004) and Goswami et al., 2015

\section{Overall Knowledge level of farmers about improved production technologies of sericulture}

It is clear from Table 2 that, majority of the respondents $(54.00 \%)$ possessed medium level of knowledge about sericulture production technologies. Whereas, 26 percent of the respondents possessed low knowledge and high knowledge level was noticed among only 20 per cent of respondents. The above results are in line with the findings of Lakshmanan and Geethadevi (2007) and Meenal and Rajan (2007).

\section{Knowledge level of farmers about improved production technologies of sericulture}

The knowledge possessed in selected improved production technologies by the sericulture farmers are presented in the Table 3 . From the Table 3, it could be observed that majority of the respondents have knowledge about the high yielding varieties and varieties suitable for their area $(92.00 \%)$ followed by irrigation management $(81.00 \%)$, transportation and marketing (78.00\%), intercropping $(75.00 \%)$, time of cocoon harvesting and deflossing $(67.00 \%)$ and method of late age rearing \& spacing $(62.00 \%)$.

This may be due to the awareness created through technology awareness programme, regular extension contract and good extension participation.

The above results are in line with the findings of Vijayaprakash and Dandin (2005), Meenal and Rajan (2007) and Srinivasulu Reddy et al., (2010) studied in sericulture.

With regards to disinfection, 58 per cent of the farmers aware of disinfection of rearing appliances and rearing house, 52 per cent of the farmers had separate rearing house, 49 per cent of farmers aware about brushing of early age worms, 47 per cent possessed knowledge about preparation of nursery bed and management and 45 per cent aware about pruning and training schedule. 
Table.1 Distribution of farmers according to their personal and socio-economic characteristics

\begin{tabular}{|c|c|c|c|c|c|}
\hline Variables & Category & No. & $\%$ & Mean & SD \\
\hline \multirow{3}{*}{ Age } & Young (Up to 35 years) & 22 & 22 & \multirow{3}{*}{39.67} & \multirow{3}{*}{---- } \\
\hline & Middle (36 to 45 years) & 56 & 56 & & \\
\hline & Old (Above 45 years) & 21 & 22 & & \\
\hline \multirow{6}{*}{ Education } & Illiterate & 20 & 20 & \multirow{6}{*}{----} & \multirow{6}{*}{---- } \\
\hline & Primary Education & 12 & 12 & & \\
\hline & Middle School & 25 & 25 & & \\
\hline & High School & 27 & 27 & & \\
\hline & PUC & 10 & 10 & & \\
\hline & Graduate and above & 07 & 07 & & \\
\hline \multirow{3}{*}{ Occupation } & Agriculture (Main) & 60 & 60 & \multirow{3}{*}{---} & \multirow{3}{*}{--- } \\
\hline & Agriculture + Subsidiary & 28 & 28 & & \\
\hline & Agriculture +Subsidiary + Other & 12 & 12 & & \\
\hline \multirow{5}{*}{ Land holding } & Marginal Farmers(Up to 2.50) & 9 & 9 & \multirow{5}{*}{8.25} & \multirow{5}{*}{--- } \\
\hline & Small Farmers (2.51 to 5.00) & 38 & 38 & & \\
\hline & Semi Medium Farmers (5-10.00) & 24 & 24 & & \\
\hline & Medium Farmers (10-25.00) & 17 & 17 & & \\
\hline & Big Farmers(Above 25.00) & 12 & 12 & & \\
\hline \multirow{3}{*}{$\begin{array}{c}\text { Family annual } \\
\text { income }\end{array}$} & Low (1 -1.30 lakh) & 41 & 41 & \multirow{3}{*}{232000} & \multirow{3}{*}{203102} \\
\hline & Medium (1.30 - 3.30 lakh) & 60 & 60 & & \\
\hline & High $(>3.30$ lakh $)$ & 19 & 19 & & \\
\hline \multirow{3}{*}{$\begin{array}{c}\text { Farming } \\
\text { Experience }\end{array}$} & $\operatorname{Low}(<4.08)$ & 26 & 26 & \multirow{3}{*}{5.98} & \multirow{3}{*}{1.90} \\
\hline & Medium(4.08- 7.88) & 54 & 54 & & \\
\hline & $\operatorname{High}(>7.88)$ & 20 & 20 & & \\
\hline \multirow{3}{*}{$\begin{array}{c}\text { Mass media } \\
\text { participation }\end{array}$} & Low $(<8.22)$ & 27 & 27 & \multirow{3}{*}{14.36} & \multirow{3}{*}{6.14} \\
\hline & Medium(8.22-20.5) & 47 & 47 & & \\
\hline & $\operatorname{High}(>20.5)$ & 16 & 16 & & \\
\hline \multirow{3}{*}{$\begin{array}{c}\text { Extension } \\
\text { participation }\end{array}$} & Low $(<1.02)$ & 27 & 27 & \multirow{3}{*}{4.48} & \multirow{3}{*}{3.46} \\
\hline & Medium(1.02-7.94) & 55 & 55 & & \\
\hline & $\operatorname{High}(>7.94)$ & 18 & 18 & & \\
\hline \multirow{3}{*}{$\begin{array}{c}\text { Extension } \\
\text { contact }\end{array}$} & Low $(<2.66)$ & 20 & 20 & \multirow{3}{*}{5.4} & \multirow{3}{*}{2.74} \\
\hline & Medium(2.66-8.14) & 62 & 62 & & \\
\hline & $\operatorname{High}(>8.14)$ & 18 & 18 & & \\
\hline & Low $(<4.26)$ & 30 & 30.00 & & \\
\hline $\begin{array}{l}\text { Scientific } \\
\text { orientation }\end{array}$ & Medium(4.26-9.08) & 54 & 36.67 & 6.67 & 2.41 \\
\hline & $\operatorname{High}(>9.08)$ & 16 & 33.33 & & \\
\hline & $\operatorname{Low}(<10.2)$ & 22 & 30.00 & & \\
\hline $\begin{array}{c}\text { Risk } \\
\text { orientation }\end{array}$ & Medium(10.2-9.08) & 44 & 36.67 & 12.8 & 2.60 \\
\hline & $\operatorname{High}(>15.4)$ & 32 & 33.33 & & \\
\hline
\end{tabular}


Table.2 Distribution of respondents in different categories of knowledge level about improved sericulture production technologies

\begin{tabular}{l|l|c|c}
\multicolumn{1}{|c|}{ Categories } & Frequency & Per cent \\
\hline Sl. No. & \multicolumn{1}{c}{$(\mathrm{n}=100)$} \\
\hline 1. & Low $(<6.31)$ & 26 & 26 \\
\hline 2. & Medium $(<6.31-14.86)$ & 54 & 54 \\
\hline 3. & High $(<14.86)$ & 20 & 20 \\
\hline & Total & 100 & 100 \\
\hline & & SD=4.26 & Mean=10.57 \\
\hline
\end{tabular}

Table.3 Improved mulberry cultivation and silkworm rearing technologies

\begin{tabular}{|c|c|c|c|}
\hline \multirow[t]{2}{*}{ SI. No } & \multirow{2}{*}{ Name of technologies } & \multicolumn{2}{|c|}{ Knowledge level } \\
\hline & & Frequency & Percentage \\
\hline A. & Mulberry cultivation technologies & & \\
\hline 1. & High yielding varieties and suitable for area & 91 & 91 \\
\hline 2. & Paired row system/ wider spacing & 41 & 41 \\
\hline 3. & Recommended fertilizer application & 38 & 38 \\
\hline 4. & Vermi composting & 32 & 32 \\
\hline 5. & Preparation of Nursery bed and management & 47 & 47 \\
\hline 6. & Irrigation management & 81 & 81 \\
\hline 7. & Intercropping & 75 & 75 \\
\hline 8. & Pruning and training schedule & 45 & 45 \\
\hline 9. & Mulberry pest and disease control & 26 & 26 \\
\hline B. & Silkworm rearing technologies & & \\
\hline 10. & Separate Chawki garden & 5 & 5 \\
\hline 11. & Separate rearing house & 52 & 52 \\
\hline 12. & Early stage (Chawki) rearing & 11 & 11 \\
\hline 13. & Method of late age rearing $\&$ spacing & 62 & 62 \\
\hline 14. & Bivoltine rearing & 19 & 22 \\
\hline 15. & Use of bed disinfectants & 41 & 41 \\
\hline 16. & $\begin{array}{l}\text { Proper maintaince of environmental and hygienic } \\
\text { conditions }\end{array}$ & 11 & 11 \\
\hline 17. & Bed Cleaning & 44 & 44 \\
\hline 18. & Brushing of worms - early & 49 & 49 \\
\hline 19. & Disinfection of rearing appliances and rearing house & 58 & 58 \\
\hline 20. & Shoot rearing method & 24 & 24 \\
\hline 21. & Incubation, hatching and Feeding & 17 & 17 \\
\hline 22. & Mounting techniques and use of rotary mountages & 31 & 31 \\
\hline 23. & Silkworm disease management & 22 & 22 \\
\hline 24. & Biological control of uzi fly & 9 & 9 \\
\hline 25. & Time of cocoon harvesting and deflossing & 67 & 67 \\
\hline 26. & Transportation and marketing & 78 & 78 \\
\hline
\end{tabular}


Table.4 Correlation between personal and socio-economic characteristics and knowledge level of farmers about sericulture production technologies $(n=100)$

\begin{tabular}{|c|l|c|}
\hline Sl. No. & Independent variables & ' $r$ ' value \\
\hline 1. & Age & $-0.213^{*}$ \\
\hline 2. & Education & $0.225^{*}$ \\
\hline 3. & Occupation & $-0.109^{\mathbf{N S}}$ \\
\hline 4. & Land holding & $0.041^{\mathbf{N S}}$ \\
\hline 5. & Family annual income & $0.018^{\mathbf{N S}}$ \\
\hline 6. & Farming experience & $0.529^{* *}$ \\
\hline 7. & Mass media exposure & $0.131^{\text {NS }}$ \\
\hline 8. & Extension participation & $0.227^{*}$ \\
\hline 9. & Extension contact & $0.218^{*}$ \\
\hline 10 & Risk taking behaviour & $0.496^{* *}$ \\
\hline 11 & Scientific orientation & $0.754^{* *}$ \\
\hline
\end{tabular}

* Significant at 0.05 level probability. **Significant at 0.01 level probability. NS -Non-significant

It is also noticed that, 44 per cent of the respondents possessed knowledge about bed cleaning. Similarly, 41 per cent aware of use of bed disinfectants and paired row system/ wider spacing. Whereas, 38 per cent and 32 per cent of the farmers were possessed knowledge about recommended fertilizer application and vermi composting. In case of pest and disease, 26 per cent and 22 per cent of the respondents possessed correct knowledge about mulberry and silkworm pest and disease and their control measures. The possible reasons could be lack of knowledge and exposure to these technologies. This was proved in many studies conducted earlier for sericulture technologies Srinivasalu (1991) and Dolli et al., (1993).

It was observed that very less per cent of the respondents possessed knowledge about separate chawki garden $(5.00 \%)$, biological control of uzi fly $(9.00 \%)$, early stage (Chawki) rearing $(11.00 \%)$, proper maintenance of environmental and hygienic conditions in silkworm rearing house $(11.00 \%)$, incubation, hatching and feeding $(17.00 \%)$ and bivoltine rearing $(19.00 \%)$. This shows that respondents might not have been exposed to the training opportunities and other extension educational activities. The results of the study are in consistency with Singhvi et al., (1993).
Relationship between selected independent variables and knowledge level of sericulture farmers

The results presented in Table 4, revealed that independent variables such as education, farming experience, extension contact, extension participation, scientific orientation and risk orientation were positively significant with knowledge level of the respondents. That mean improvement in these variables of the respondents contributes for increase in their knowledge level of sericulture production practices. Therefore, these factors may be taken in to consideration for creating more awareness about the improved technologies among the sericulture farmers. The results of the study are in consistency with Lakshmanan and Geethadevi (2007) and Vijayakumari and Rajan (2006) reported in sericulture. Only age exhibited negatively non-significant relationship with the knowledge level of respondents. The other variables such as occupation, land holding, family annual income and mass media participation were no significant relationship with knowledge level of the respondents. That means these variables of the respondents not contributed for increase in their knowledge level of sericulture production technologies. 
The study revealed that in most of the improved technologies of sericulture, the knowledge level of the respondents was medium to high level. The socio-economic characters like education, experience, extension contact, extension participation, scientific orientation and risk orientation have a significant association with the knowledge level of the respondents about improved technologies. Therefore, these factors may be taken in to consideration for creating more awareness about the improved technologies among the sericulture farmers to produce the raw silk in to a desired level.

\section{References}

Barah, A., Mech, D., Singh, K.C. and Suryanarayana, N. (2004) "Yield gap: A major prodigium in muga silk industry", Journal of Assam Science Society, 45(1), 19-28.

Dolli, S.S., Kalappa, H.K., Subramaniam, R.K., Chikkanna, Singhvi, N.R., Sen, A.K., Iyengar, M.N.S. and Datta, R.K. (1993). Extent of adoption of improved sericulture practices by the sericulturists. Indian Silk, 31 (10): 3540. Karnataka (India).

Goswami, N.K., Nath, P. and Saharia, D. (2015), "A study on socio-economic assessment and adoption of scientific technologies by the muga rearers of Assam", International Journal of Scientific Research.4 (2):349-353

Lakshmanan, S. and Geethadevi, R. G. (2007), "Knowledge and adoption levels of farmers of bivoltine and cross breed sericultural technologies", Indian $J$. Seric., 46(1): 72-75.

Mech, D., Borah, A., Singh, K.C. and Surynarayana, N. (2004), "Adoption of improved technology package and its impact on production in muga - A case study", Indian J. Seric, 43(1): 95-98

Meenal, R. 2008. Impact of adoption of bivoltine sericulture technologies by farmers in Erode District, Tamil Nadu. Ph.D. thesis. University of Mysore, Mysore, Karnataka (India).

Meenal, R. and Rajan, R. K. (2007), "Impact of socio-economic characters of sericulturists on knowledge and adoption and cocoon production in Tamil Nadu", Indian J. Seric., 46(1): 49-51.

Singhvi, N.R., Chakrabarti, S., Singhal, B.K., Thippeswamy, T. and Datta, R.K. (1993). Extent of adoption of recommended practices by mulberry growers. J. Seric., 4(1): 33-34.

Srinivasalu, V.M. (1991). Socio-economic conditions of sericulturists in relation to adoption of new sericultural technologies in Karnataka State. STS Dissertation, ICTRETS, Mysore (Karnataka) India.

Srinivasulu Reddy, P., Sujatha, B., Kasireddy, B., Rao, T. V. S., Vijayanaidu, B. and Satyanarayanaraju, C. (2010), "Knowledge and adoption of bivoltine sericulture technologies by farmers of Anantapur, Chittor and Coastal districts of Andra Pradesh - A comparative study", Indian J. Seric., 49 (1):70-75.

Vijay prakash, N. B. and Dandin, S. B. (2005), "Factors influencing the adoption of bivoltine sericultural practices in Mandya District of Kamataka", Indian J. Seric, 44(1): 55-58.

Vijayakumari and Rajan (2006), "Adoption level of technologies by commercial chawki rearing centre owners in Kamataka", Indian J. Seric., 45(1): 710 .

\section{How to cite this article:}

Hadimani, D.K., Moulasab, J. Ashoka and Manjunath. 2017. A Impact Study on Sericulture Production Technologies by the Farmers of Bidar District in Hyderbad Karnataka. Int.J.Curr.Microbiol.App.Sci. 6(11): 2368-2374. doi: https://doi.org/10.20546/ijcmas.2017.611.280 